
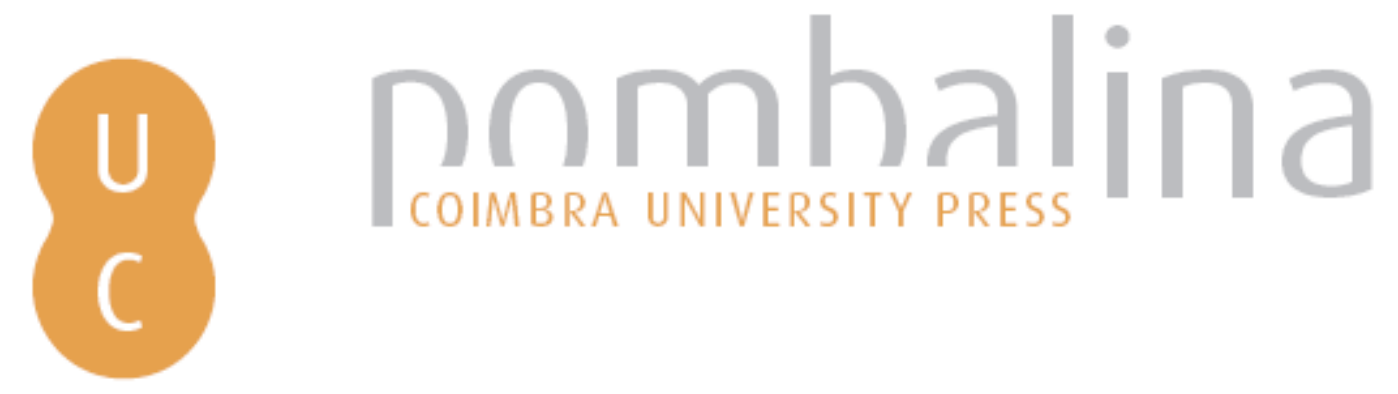

\title{
A tradição peripatética no livro $V$ de Diógenes Laércio: um conspecto
}

\author{
Autor(es): $\quad$ Mesquita, António Pedro
}

Publicado por: Imprensa da Universidade de Coimbra

URL

persistente: URI:http://hdl.handle.net/10316.2/34711

DOI: $\quad$ DOI:http://dx.doi.org/10.14195/978-989-721-042-6_11

Accessed : $\quad$ 26-Apr-2023 15:37:28

A navegação consulta e descarregamento dos títulos inseridos nas Bibliotecas Digitais UC Digitalis, UC Pombalina e UC Impactum, pressupõem a aceitação plena e sem reservas dos Termos e Condições de Uso destas Bibliotecas Digitais, disponíveis em https://digitalis.uc.pt/pt-pt/termos.

Conforme exposto nos referidos Termos e Condições de Uso, o descarregamento de títulos de acesso restrito requer uma licença válida de autorização devendo o utilizador aceder ao(s) documento(s) a partir de um endereço de IP da instituição detentora da supramencionada licença.

Ao utilizador é apenas permitido o descarregamento para uso pessoal, pelo que o emprego do(s) título(s) descarregado(s) para outro fim, designadamente comercial, carece de autorização do respetivo autor ou editor da obra.

Na medida em que todas as obras da UC Digitalis se encontram protegidas pelo Código do Direito de Autor e Direitos Conexos e demais legislação aplicável, toda a cópia, parcial ou total, deste documento, nos casos em que é legalmente admitida, deverá conter ou fazer-se acompanhar por este aviso.

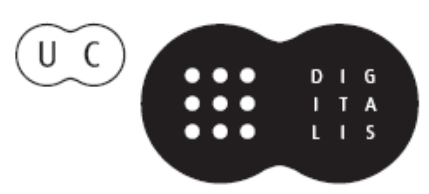




\section{Dos Homens e suas Ideias \\ Estudos sobre as Vidas de Diógenes Laércio}

Delfim Leão, Gabriele Cornelli \& Miriam C. Peixoto (coords.) 


\title{
A Tradição Peripatética no Livro V de Diógenes LAÉrcio: UM ConsPeCto (The Peripatetic tradition in Diogenes Laertius' Book V: An overview)
}

\author{
António Pedro Mesquita \\ Centro de Filosofia da Universidade de Lisboa
}

Resumo: $\mathrm{O}$ presente artigo apresenta esquematicamente o conteúdo do livro $\mathrm{V}$ das Vidas e Doutrinas dos Filósofos Ilustres de Diógenes Laércio, dedicado às seguintes figuras da escola peripatética ou a ela ligadas: Aristóteles de Estagira (384-322 a.C.), Teofrasto de Éreso (372-287 a.C.), Estratão de Lâmpsaco (335-269 a.C.), Lícon de Troa (c. 299-225 a.C.), Demétrio de Faleros (c. 360-280 a.C.) e Heraclides Pôntico (c. 390-310 a.C.). Para esse efeito, segue o padrão de abordagem adoptado pelo próprio Diógenes nas biografias (vida, personalidade e aparência pessoal; testamento; ditos; doutrinas; catálogo dos escritos; personagens célebres com o mesmo nome), mas seleccionando apenas os aspectos mais relevantes e cotejando sempre criticamente a informação provinda do autor com aquela que fontes independentes e a investigação mais actualizada permitam confirmar.

Palavras-chave: Aristóteles, aristotelismo, Liceu, Perípato, peripatético, Teofrasto, Estratão, Lícon, Demétrio de Faleros, Heraclides Pôntico

Авsтract: This paper intends to provide an outline of the contents of book $V$ of Diogenes Laertius' Lives and Opinions of Eminent Philosophers, devoted to the following figures of the Peripatetic School or somehow related to it: Aristotle of Stagira (384-322 B.C.), Theophrastus of Eresus (372-287 B.C.), Strato of Lampsacus (335-269 B.C.), Lyco of Troas (c. 299-225 B.C.), Demetrius of Phalerum (c. 360-280 B.C.) and Heraclides Ponticus (c. 390-310 B.C.). In order to fulfill this purpose, we shall follow the pattern of approach adopted by Diogenes himself in these biographies (life, personality and personal appearance; last will and testament; sayings; doctrines; catalogue of writings; famous people bearing the same name), but selecting only the most relevant aspects and systematically confronting them with the information provided by independent sources and confirmed by the latest research.

Key-words: Aristotle, aristotelianism, Lyceum, Peripatos, peripatetic, Theophrastus, Strato, Lyco, Demetrius of Phalerum, Heraclides Ponticus

\section{Estrutura e padrão de composição}

O livro V das Vidas e Doutrinas dos Filósofos Ilustres de Diógenes Laércio é constituído por seis capítulos, dedicados às seguintes figuras da escola peripatética ou a ela ligadas: Aristóteles de Estagira (384-322 a.C.), Teofrasto de Éreso (372287 a.C.), Estratão de Lâmpsaco (335-269 a.C.), Lícon de Troa (c. 299-225 a.C.), Demétrio de Faleros (c. 360-280 a.C.) e Heraclides Pôntico (c. 390-310 a.C.). 
Há neste elenco alguns aspectos curiosos.

O primeiro é a manifesta heterogeneidade de conteúdo, associando os quatro primeiros escolarcas do Liceu ${ }^{1}$ a duas personalidades 'avulsas', ambas do período mais antigo, contemporâneas de Aristóteles e Teofrasto.

O segundo é a ausência dos restantes escolarcas conhecidos do Perípato ${ }^{2}$, todos, muito embora, largamente anteriores a Diógenes Laércio e que, portanto, dificilmente lhe poderiam ser alheios. Aliás, o livro imediatamente precedente das Vidas, dedicado à Academia, mostra que Diógenes conhecia perfeitamente os respectivos directores na época dos responsáveis omitidos da escola peripatética ${ }^{3}$.

Um terceiro aspecto curioso é a falta de referência a outras figuras importantes do círculo aristotélico, por exemplo, nos tempos de Aristóteles, Aristóxeno de Tarento ${ }^{4}$ ou Eudemo de Rodes ${ }^{5}$, nos de Teofrasto, Dicearco de Messana ${ }^{6}$,Fânias de Éreso $^{7}$ ou Clearco de $\mathrm{Solos}^{8}$, ou ainda, em tempos mais recentes, Jerónimo de Rodes ${ }^{9}$ ou Sócion de Alexandria, o inventor do método das sucessões, que o próprio Diógenes Laércio adopta sistematicamente. Excepções, sempre pontuais, para além do próprio Sócion ${ }^{10}$, são Aristóxeno, citado como fonte na

\footnotetext{
${ }^{1}$ Depois do fundador, governaram sucessivamente a escola: Teofrasto, entre 322 e 287 a.C.; Estratão, entre 287 e 269 a.C.; e Lícon, entre 269 e 225 a.C.

${ }^{2}$ A seguir a Lícon, dirigiram o Liceu: Aríston de Cós, entre 225 e 190 a.C.; Critolau de Fáselis, entre 190 e 155 a.C.; e, ao longo da segunda metade do século II a.C., Diodoro de Tiro e Erimeneu, o último escolarca do Perípato de que há memória na sucessão iniciada em Aristóteles (as respectivas datas não chegaram até nós). Há várias listas antigas dos escolarcas do Liceu, todas contrastantes entre si; para um balanço da informação nelas contidas, cf. Brink 1940.

${ }^{3}$ Em particular, Carnéades de Cirene e Clitómaco de Cartago, que governaram a escola platónica entre 155-129 a.C. e 129-110 a.C., respectivamente, coincidindo, pois, com o período dos dois últimos escolarcas conhecidos do Perípato, Diodoro e Erimeneu (ver a nota anterior).

${ }^{4}$ Discípulo de Aristóteles, notabilizou-se especialmente pelos seus estudos no domínio da harmonia, de que foi o grande teorizador. Coligiu também as biografias de diversos filósofos, entre os quais Pitágoras, Arquitas e Platão.

${ }^{5}$ Matemático e astrónomo do círculo peripatético, foi contemporâneo de Teofrasto no Liceu, após o que fundou uma escola própria na sua cidade natal.

${ }^{6}$ Intelectual singularmente proteiforme do círculo peripatético, foi discípulo de Aristóteles no Liceu, vindo a distinguir-se como historiador, geógrafo, matemático e filósofo.

${ }^{7}$ Filósofo peripatético, pensa-se que terá entrado no Liceu ainda em vida de Aristóteles. Dedicou-se sobretudo à lógica, à botânica e à história, mas os seus escritos não sobreviveram, assim como não os comentários aos primeiros tratados do Organon que lhe são atribuídos.

${ }^{8}$ Filósofo peripatético da segunda geração, natural de Chipre, foi membro do Liceu durante a direcção de Teofrasto. Dedicou-se especialmente à descrição das culturas orientais, que parece ter conhecido directamente ao longo de diversas viagens.

${ }^{9}$ Escritor peripatético do tempo de Lícon e de Aríston, compilou uma obra hipomnemática muito ao gosto do helenismo, em que os doxógrafos posteriores se inspiraram abundantemente. Parece ter-se oposto a Arcesilau, fundador e escolarca da Academia Média, e ao próprio Lícon, desenvolvendo uma ética singularmente próxima do estoicismo.

${ }^{10}$ Nominalmente mencionado duas vezes, em 5.79 e 86, embora, na primeira, no contexto do epítome da sua obra realizado por Heraclides Lembo.
} 
Vida de Aristóteles e na de Heraclides ${ }^{11}$, Fânias, indicado como destinatário de uma carta de Teofrasto na notícia relativa a este ${ }^{12}$,e Jerónimo, cujo antagonismo com Lícon surge referido na biografia deste último ${ }^{13}$.

Um outro aspecto digno de menção, pela bizarria, é a sucessão irregular das notícias sob o ponto de vista temporal: após Lícon, em pleno século III a.C. avançado, regressa-se a Demétrio de Faleros, no final do século IV.

Finalmente, um último aspecto enigmático é a inclusão no livro dedicado ao Perípato de Heraclides Pôntico, um académico, que, tanto quanto podemos apurar pelas melhores fontes ${ }^{14}$, só saiu da escola platónica aquando da eleição para substituir Espeusipo, em 339 a.C. (quase dez anos depois, portanto, do abandono do Estagirita) e apenas em virtude de a haver perdido para Xenócrates, após o que, longe de se juntar a Aristóteles, ainda no exílio, fundou uma escola própria na sua pátria, Heracleia, no Mar Negro (o Ponto Euxino ou simplesmente o Ponto - dos gregos) $)^{15}$.

Claro que nada disto é original na obra de Diógenes, mas dá, de algum modo, o timbre do livro sob exame.

Uma explicação para parte destes fenómenos poderá estar nas fontes usadas pelo doxógrafo, as principais das quais, para a transmissão das biografias, serão do século III a.C., como é o caso, notavelmente, de Hermipo de Esmirna (não anteriores, portanto, a Lícon), ou dependem por sua vez de fontes que lhe são contemporâneas (por exemplo, Aríston de Cós, expressamente citado, conforme vimos, como autor da recolha dos testamentos dos escolarcas que o antecederam à frente do Liceu $)^{16}$.

Outras dificuldades terão justificações mais simples e resultam, por vezes, das próprias metodologias históricas e narrativas de Diógenes. Assim, por exemplo, a falha de cronologia que se verifica na transição da biografia de Lícon para a de Demétrio parece ficar a dever-se ao autor preferir privilegiar, em detrimento dela, a sucessão dos quatro escolarcas cujas biografias conhecia, em vez de a quebrar com a introdução de outros nomes no lance cronologicamente pertinente. Por outro lado, a inclusão de Heraclides Pôntico segue o modelo,

${ }^{11}$ Cf., respectivamente, 5.35 e 92 .

${ }^{12}$ Cf. 5.37. O seu nome ocorre novamente em 5.50, no interior de uma colecção de correspondência incluída como item bibliográfico no catálogo de escritos de Teofrasto.

${ }^{13}$ Cf. 5.68. Para além destes, o quinto escolarca do Liceu, Aríston de Cós, também é referido marginalmente três vezes: como fonte para o conhecimento dos testamentos dos quatro escolarcas precedentes (5.64); e duas vezes no interior do testamento de Lícon (5.70 e 74).

${ }^{14}$ Hoje, todas acessíveis em Schütrumpf 2008.

${ }^{15}$ Cf., em especial: Estrabão 12.3.1, 541.1-3 (= frg. 2 Schütrumpf); Suda, s.v. "Heraclides" (= frg. 3 Schütrumpf); Diógenes Laércio 3.46 (= frg. 6 Schütrumpf); Filodemo, Herc. 1021 col. 5.32-6.10 (= frg. 7 Schütrumpf); Filodemo, Herc. 1021 col. 6.41-7.10 (= frg. 10 Schütrumpf); Cícero, Leg. 3.6.14 (= frg. 30 Schütrumpf); N.D. 1.13.34 (= frg. 72 Schütrumpf); Tusc. 5.3.8-9 (= frg. 85 Schütrumpf); e Div. 1.23 .46 (= frg. 117a Schütrumpf).

${ }^{16}$ Cf. 5.64 e nota 13 , supra. 
muito típico da doxografia antiga, de arregimentação forçada das figuras de enquadramento difícil, como sucede também, no Livro IX, com Xenófanes de Cólofon, chamado a apadrinhar a escola eleática a despeito da sua origem jónica e do teor nada itálico da sua reflexão conhecida.

Ao longo dos seis capítulos, o padrão de abordagem seguido por Diógenes é semelhante ao que encontramos nos outros livros e consiste em percorrer para cada filósofo, nem sempre por esta ordem, os seguintes tópicos:

- vida, personalidade e aparência pessoal;

- testamento;

- apotegmas;

- doutrinas;

- lista de escritos;

- personagens célebres com o mesmo nome.

Como nos restantes livros, nem todos os biografados fazem o pleno desta descrição. Assim, só os quatro primeiros têm direito à transcrição do testamento (já sabemos o motivo: porque Diógenes o colheu em, ou numa fonte que repousa em, Aríston de Cós, o quinto escolarca do Liceu); apenas Aristóteles e Demétrio vêm os seus ditos famosos registados e só o primeiro conta com uma resenha doutrinária (o pressuposto, falso, parece ser o de que o fundador definiu de uma vez por todas o pensamento da escola); os catálogos de escritos saltam Lícon, cuja obra não é referida (há, de resto, uma referência na Vida que sugere ter sido este um autor sobretudo 'oral') ${ }^{17}$; e, no capítulo relativo a Teofrasto, não há referência a outras personagens com o mesmo nome, pela simples razão de que este não era o seu nome próprio, mas uma alcunha ${ }^{18}$.

No presente conspecto, seguiremos também este padrão relativamente a cada uma das seis figuras tratadas por Diógenes Laércio, mas seleccionando apenas os aspectos relevantes e procurando sempre cotejar criticamente a informação provinda do nosso autor com aquela que fontes independentes permitam confirmar.

\section{Aristóteles ${ }^{19}$}

Diógenes Laércio está longe de ser a nossa única fonte para o conhecimento da biografia do Estagirita.

${ }^{17}$ Cf. 5.66 e, infra, pp. 18-19.

${ }^{18}$ Cf. 5.38 .

19 Algumas passagens desta secção e da próxima recuperam, com adaptações, textos originalmente incluídos na nossa Introdução Geral às Obras Completas de Aristóteles (2005), cuja leitura poderá ser útil para um complemento informativo mais pormenorizado. Para o conjunto do livro V, a melhor exposição é ainda a de Sollenberger (1992), que recomendamos vivamente ao leitor interessado numa análise mais profunda e exaustiva. 
Pelo contrário, para além de numerosos testemunhos avulsos, existem nada menos do que doze Vidas antigas de Aristóteles: cinco em grego, entre as quais a de Diógenes, uma em latim, duas em siríaco e quatro em árabe.

No entanto, a sua notícia mostra-se notavelmente isenta dos tiques e exageros hagiográficos que caracterizam o tratamento neoplatónico dos materiais biográficos (que é o que preside a todas as outras biografias, com excepção de uma outra grega, a de Hesíquio $^{20}$ ), o que reforça a conjectura de que corresponda ao desenvolvimento de um antigo filão peripatético, designadamente radicando na obra Sobre Aristóteles, hoje perdida, de Hermipo de Esmirna. Daí a sua particular relevância.

Entre as fontes expressamente referidas por Diógenes Laércio ${ }^{21}$, as principais, para além do próprio Hermipo ${ }^{22}$, frequentemente citado, são as Crónicas de Apolodoro de Atenas (século II a.C. ${ }^{23}$ e as Miscelâneas e Memoráveis de Favorino de Arelate (c. 80-160 d.C. ${ }^{24}$, todas mencionadas sobretudo para o estabelecimento da cronologia da vida de Aristóteles.

Fontes mais pontuais são as Histórias de Eumelo (séculos IV-III a.C.)25, onde vai buscar informações (erradas) sobre a morte de Aristóteles ${ }^{26}$, o dicionário Poetas e Escritores com o Mesmo Nome de Demétrio de Magnésia (século I a.C. ${ }^{27}$, que lhe fornece detalhes sobre os alegados laços de parentesco

${ }^{20}$ Trata-se da Vita Hesychii, assim designada porque a sua origem é justamente atribuída ao verbete 'Aristóteles' do Onomatólogo de Hesíquio de Mileto (século VI). Este foi reproduzido pela Suda (sem o catálogo dos escritos) e editada modernamente pela primeira vez (com o catálogo) por Gilles Ménage em 1663, como apêndice à sua edição de Diógenes Laércio (razão pela qual é também habitualmente conhecida por Vita Menagiana).

21 "Expressamente referidas", porque há abundante material para o qual Diógenes nunca revela as suas fontes, por exemplo os catálogos dos escritos, ou só vem a revelar em bloco mais à frente, como é o caso de Aríston de Cós para os testamentos dos escolarcas do Liceu.

${ }^{22}$ Hermipo de Esmirna (século III a.C.) foi um bibliotecário de Alexandria pertencente ao círculo peripatético, a quem se deve a mais antiga biografia conhecida de Aristóteles. Tudo leva a crer que esta foi preservada, pelo menos em parte, pelas notícias de Diógenes Laércio e de Hesíquio de Mileto. Poderá também dever-se-lhe o catálogo peripatético das obras de Aristóteles que chegou aos nossos dias através das duas versões preservadas por estes dois autores.

${ }^{23}$ Gramático ateniense radicado em Alexandria, publicou uma obra em versos jâmbicos intitulada Crónicas, onde se estipulava a cronologia dos filósofos anteriores a partir da determinação da data do seu apogeu (a akme), que se fazia coincidir com os 40 anos de idade.

${ }^{24}$ Filósofo céptico e hábil dialecta na época da segunda sofística, representa bem a diversidade cultural do império romano nos tempos de Trajano e Adriano: gaulês de origem, era cidadão romano e usava o grego para escrever e ensinar. Foi amigo pessoal de Plutarco e parece ter construído uma obra pelo menos tão vasta como a dele, de que, no entanto, só subsistem alguns fragmentos, preservados por Aulo Gélio, Filóstrato de Lemnos e Diógenes Laércio, para além de outros mais tardios.

${ }^{25}$ Autor contemporâneo do historiador da Ática Filócoro de Atenas, parece ter escrito uma obra apologética sobre Aristóteles, de que, todavia, só subsiste um curto fragmento.

${ }^{26}$ Cf. 5.6.

27 Doxógrafo helenístico, criou o método das homonímias, que consistia em tratar 
estabelecidos entre Aristóteles e Hermias de Atarneu ${ }^{28}$, as Vidas de Timóteo de Atenas (século II-III) ${ }^{29}$, onde se baseia para as características pessoais de Aristóteles $^{30}$ e a Vida de Platão de Aristóxeno de Tarento, que lhe faculta a identidade de uma outra personalidade chamada 'Aristóteles' ${ }^{31}$.

Para além destas, algumas fontes de que Diógenes se serve são abertamente desfavoráveis a Aristóteles, ou mesmo caluniosas. Entram nesta categoria Timeu de Tauroménio (c. 345-250 a.C. . $^{32}$, onde ele encontra uma versão da estrutura familiar de Aristóteles ${ }^{33}$; um tal Aristipo $^{34}$, cuja sugestiva obra Sobre a Luxúria dos Antigos cita para sustentar certos pormenores, que se pretendiam escandalosos, da sua vida sentimenta1 ${ }^{35}$; Teócrito de Quios (séculos IV-III a.C.), de quem preserva, através do seu epígono e conterrâneo Bríon (ou Ambríon), um epigrama verrinoso estigmatizando supostas relações condenáveis entre Hermias e Aristóteles, aquando da sua estadia em Atarneu ${ }^{36}$; e Tímon de Fliunte (c. 325-253 a.C. ${ }^{37}$, de quem conserva um outro epigrama, mais curto,

conjuntamente os escritores com o mesmo nome.

${ }^{28}$ Cf. 5.3. Hermias de Atarneu foi um tirano de Asso e Atarneu, na Ásia Menor, entre 451 e 441 a.C., altura em que foi deposto e condenado à morte pelo rei Artaxerxes III da Pérsia. Muito próximo do círculo platónico, foi durante o seu governo directamente aconselhado por dois discípulos de Platão, Corisco e Erasto, como a Carta VI, que aquele lhes endereça, testemunha. Um pouco mais tarde, recebeu Aristóteles e Xenócrates, estabelecendo com aquele relações de amizade que muito contribuíram para alimentar a literatura anti-aristotélica.

${ }^{29} \mathrm{Nada}$ se sabe sobre este autor, que só surge referido em Diógenes Laércio. A sua identidade com Timóteo de Pérgamo, a quem se atribui uma obra sobre a virtude dos filósofos, permanece por decidir.

${ }^{30}$ Cf. 5.1.

${ }^{31}$ Cf. 5.35 .

${ }^{32}$ Historiador grego de origem siciliana, passou a maior parte da vida em Atenas, onde se havia exilado por motivos políticos. Aí, redigiu uma História da Sicília, em 38 (ou 33) volumes, de que se conservam alguns fragmentos. Esta, muito criticada pelos antigos pela sua parcialidade e falta de rigor, teve, no entanto, alguns defensores, nomeadamente Cícero. Constitui um dos elos antigos da transmissão da tradição hostil a Aristóteles, em particular de origem isocrática e epicurista.

${ }^{33}$ Cf. 5.1. De acordo com essa versão, após a morte da mulher, Pitíade, Aristóteles teria tomado como concubina uma mulher de nome Herpílis, de quem Nicómaco seria filho. Noutras versões, que Diógenes aparentemente ignora, Herpílis é apresentada como esposa legítima de Aristóteles e Nicómaco como filho de ambos, o que ressalta o carácter potencialmente negativo da história veiculada por Timeu. Para esta polémica, veja-se o nosso livro Vida de Aristóteles (2006).

${ }^{34}$ Quase nada se sabe sobre este autor, salvo que terá sido um historiador da Arcádia (segundo o próprio Diógenes Laércio: cf. 2.83).

35 "Aristóteles apaixonou-se por uma concubina de Hermias..." (5.3).

${ }^{36} \mathrm{Cf}$. 5.11. Poeta, orador da escola isocrática e militante anti-macedónico, Teócrito de Quios tinha todos os motivos para antipatizar com Aristóteles. De Bríon, só se sabe ter escrito um panegírico Sobre Teócrito, cuja fama deriva exclusivamente deste epigrama.

${ }^{37}$ Poeta satírico e filósofo céptico grego, foi aluno, em Atenas, de Estílpon de Mégara e de Pirro de Élis, a cujo magistério se associou. Escreveu diversas obras, de que as mais célebres são os Silloi, poemas em versos hexâmetros em que caricatura e vergasta os filósofos dogmáticos seus 
atacando a 'futilidade' de Aristóteles ${ }^{38}$.

A notícia relativa a Aristóteles é a mais extensa e completa de todas as incluídas no livro V.

De acordo com o padrão geral, apresenta a seguinte estrutura:

- vida, personalidade e aparência (1-10);

- testamento (11-15);

- ditos (16-21);

- catálogo dos escritos (22-27);

- doutrinas (28-34);

- personagens famosas com o nome 'Aristóteles' (35).

No apartado propriamente biográfico, encontram-se informações relativas ao nascimento e à família (5.1); à aparência (era, pelo vistos, gago ou ceoso, tinha olhos pequenos e pernas delgadas, mas "dava nas vistas pela roupa, os anéis e o corte do cabelo" [ib.]); à relação com Platão e a Academia (com o dado, relevante, de que teria abandonado a escola enquanto Platão ainda era vivo) (5.2); às viagens pela Ásia Menor e à partida para a Macedónia como preceptor de Alexandre (5.3-4); ao regresso a Atenas e à fundação da sua própria escola "num passeio público (peripaton) no Liceu, para andar para cima e para baixo (anakamptonta) a filosofar em conjunto com os discípulos até à hora da unção - donde o nome 'peripatético' (peripatetikon)" (5.2, 6-9); e aos últimos tempos de vida, com destaque para a acusação por impiedade que lhe foi dirigida por causa do hino dedicado a Hermias ${ }^{39}$ e da inscrição por ele colocada na sua estátua em Delfos e, em consequência, ao segundo e definitivo exílio e à morte em Cálcis (5.5-6). A secção termina com a transcrição completa da cronologia de Apolodoro (5.9-10).

A passagem relativa ao testamento ${ }^{40}$, também transcrito integralmente, é sobretudo importante para a fixação de alguns laços familiares (relativos às mulheres, Pitíade e Herpílis, aos filhos, Pitíade e Nicómaco, aos irmãos, Arimnesto e Arimnesta, ao sobrinho, Nicanor, etc.) e a determinação das figuras do seu círculo mais próximo, nomeadamente Teofrasto e Antípatro, o colaborador de Alexandre e futuro governante da Macedónia ${ }^{41}$.

Seguem-se os apotegmas (5.16-21), de que raros podem ser considerados genuínos, no sentido de corresponderem ao conteúdo das obras preservadas de Aristóteles. Para mais, a compilação provém de diversas fontes e contém alguns ditos atribuídos a outros autores.

predecessores ou contemporâneos.

${ }^{38}$ Cf. 5.11.

${ }^{39}$ Citado integralmente em 5.7-8.

40 5.11-15. Os testamentos dos peripatéticos foram cuidadosamente estudados por Gottschalk (1972) e por Sollenberger (1992).

${ }^{41}$ Para estes aspectos, pode igualmente ler-se o livro referido supra, na nota 33. 
A secção seguinte, que contém as lista das obras de Aristóteles (5.22-27),é particularmente importante. Com efeito, com os outros dois inventários antigos que se conhecem, o de Hesíquio e respectivo apêndice (dito vulgarmente 'anónimo', porque a sua origem não está absolutamente assegurada) e o de Ptolemeu ${ }^{42}$, nas suas coincidências, mas sobretudo nas suas divergências, é fundamental para o conhecimento e a compreensão da evolução do corpus aristotélico ${ }^{43}$.

O catálogo de Diógenes é constituído por 146 títulos, na sua maioria desconhecidos e à primeira vista inventariados sem qualquer ordem.

Os textos correspondem maioritariamente a diálogos, exortações e estudos platónicos (com que o catálogo abre: títulos 1-24), a um número impressionante de tratados, recolhas, pequenos estudos, manuais e cadernos de exercícios de lógica (25-73), na sua maior parte sem paralelo no corpus conservado, bem como a recolhas documentais e compilações (117-143), a que se juntam alguns, poucos, tratados.

O catálogo está recheado de títulos curiosos como Acerca dos Animais Mitológicos (106), Sinais de Tempestade (112) e Conjunções Astrais (126), ou enigmáticos como Outra Arte (80), Miscelâneas (127) e Explicações por Ordem de Assunto (128).

O mais provocativo, porém, é que a maior parte dos tratados do corpus moderno se encontra ausente, o que afecta nomeadamente a Física (em versão completa), o Sobre o Céu, o Sobre a Geração e a Corrupção, os Meteorológicos, o Sobre a Alma, a totalidade dos tratados biológicos (com excepção da História dos Animais), a Metafísica e a Ética a Nicómaco, para citar apenas as ausências mais significativas.

Parte substancial destes mistérios foi concludentemente explicada por Paul Moraux, na sua obra pioneira sobre o assunto ${ }^{44}$, onde justifica também a peculiar disposição com que o catálogo se apresenta ${ }^{45}$.

Finalmente, a secção doutrinária ${ }^{46}$ contém uma súmula extensa e, dadas as limitações do autor, notavelmente rigorosa de algumas das principais doutrinas de Aristóteles, sem recurso visível a fontes, o que faz suspeitar de uma leitura, pelo menos em parte, directa.

${ }^{42}$ Autor desconhecido e de identificação muito discutida, já na Antiguidade (os árabes distinguiram-no pelo epíteto al garib, que significa justamente "o desconhecido"), poderá ter sido um neoplatónico alexandrino do século IV d.C., talvez pertencente à escola de Jâmblico, a quem devemos uma biografia e um catálogo das obras de Aristóteles, conhecido apenas por retroversão de versões árabes.

${ }^{43}$ Tentámos mostrá-lo detalhadamente no primeiro estudo incluído na Introdução Geral às Obras Completas de Aristóteles, para o qual remetemos o leitor.

${ }^{44}$ Moraux 1951.

${ }^{45}$ Para o detalhe, recomendamos uma vez mais o trabalho mencionado na nota 43, supra.

${ }^{46}$ 5.28-34. O mais recente editor da obra de Diógenes Laércio, Tiziano Dorandi, apresentou já esta secção do livro V em Dorandi 2007. 
O esquema analítico de que Diógenes se serve, começando por apresentar as "divisões da filosofia de Aristóteles" (5.28) para, em seguida, passar à exposição das suas doutrinas em lógica, em ética e em física ${ }^{47}$,é, obviamente, de origem estóica, mas, à época, já a classificação subjacente se tinha tornado escolar e generalizado, sem denunciar, pelo seu uso, qualquer adesão a uma escola filosófica particular ou especificamente ao estoicismo.

E a prova é que, quando Diógenes apresenta a posição de Aristóteles nesta matéria, fá-lo com rigor. Com efeito, a divisão da filosofia em teórica, prática e produtiva, que lhe atribui, é distintamente aristotélica e, aliás, frequente nos textos do Estagirita pelo menos desde o Protréptico ${ }^{48}$. Também a subdivisão da parte prática em ética, economia e política é plenamente aristotélica. Só a subdivisão da parte teórica em física e lógica ecoa uma contaminação estóica.

Reconhecidamente, este ponto é controverso, porque a generalidade dos eruditos que se dedicou a estudar esta passagem do livro $\mathrm{V}$ insistiu na leitura contrária, a saber, no carácter não peripatético da resenha doutrinária de Diógenes, baseando-se, em especial, na ocorrência de certos conceitos e princípios estóicos ${ }^{49}$.

É certo que a súmula transparece uma espécie de estoicismo esquemático ou escolar, desde logo na estrutura adoptada para a exposição, de que já falámos, mas também em parte significativa da linguagem e dos conceitos utilizados, como os de critério de verdade, de sábio ou de providência.

Contudo, no essencial, o registo do próprio conteúdo do pensamento de Aristóteles é adequado, não apenas na divisão da filosofia que lhe é imputada, como já referimos, mas, por exemplo, na ideia tão retintamente peripatética, e tão oposta ao sistema estóico, de que a lógica é um instrumento da filosofia e não uma sua parte ${ }^{50}$ ou na afirmação de certas teses aristotélicas, nos antípodas das estóicas, de acordo com as quais deus e a alma são incorpóreos ${ }^{51}$ ou a virtude não é condição suficiente da felicidade ${ }^{52}$, para além de muitas outras, como a concepção de amizade, a doutrina dos três tipos de vida e do primado da vida contemplativa, a definição canónica de alma como acto primeiro de um corpo com a vida em potência, a doutrina dos cinco elementos e do movimento circular do éter, etc. ${ }^{53}$

${ }^{47}$ Respectivamente, 5.29, 30-31 e 32-34.

${ }^{48}$ Veja-se, por exemplo: Protrepticus 6W $=6 \mathrm{R}=59-70 \mathrm{D}=55-66 \mathrm{C} ;$ Top. 6.145a13-18; 8.157a8-11; Metaph.5.1025b18-30; 5.1026b5; 10.1064a10-19; EN6.1139a27-31; 10.1178b2021.

${ }^{49}$ Cf. Moraux 1949 e 1986; Bodéus 1986 e 1995. Ver também o artigo de Dorandi referido supra, nota 46.

${ }^{50}$ Cf. $5.28,5-6$.

${ }^{51}$ Cf. $5.32,3-4$ e 8-9.

${ }^{52}$ Cf. $5.30,1-10$.

${ }^{53}$ Cf. respectivamente: 5.31.4-5; 31.8-9; 32.9-10; 32.6-9. 


\section{Teofrasto}

Ao contrário do que sucede com Aristóteles, Diógenes Laércio é a nossa principal fonte para a biografia de Teofrasto.

Por sua vez, as fontes que ele próprio refere são surpreendentemente poucas, muito menos do que as que encontrámos no capítulo precedente.

Retomam-se dele: Favorino, sem identificação de obra (uma única referência $)^{54}$; e Aristipo, uma vez mais em Sobre a Luxúria dos Antigos, sempre no registo da bisbilhotice (Teofrasto "estava apaixonado pelo filho [de Aristóteles], Nicómaco, embora fosse seu professor...”) (5.39.1-3, sublinhado nosso).

A estas, juntam-se apenas três outras referências menores, todas no início da notícia (5.36): as Digressóes de Atenodoro Cananeu (c. 74 a.C. - 7 d.C.) ${ }^{55}$; os Paralelos Históricos de Mironiano de Amástris ${ }^{56}$; e as Memoráveis de Pânfila de Epidauro (século I) ${ }^{57}$.

Tudo leva a crer que a fonte principal de Diógenes, para esta como para as outras biografias peripatéticas, se mantém em geral por explicitar, ou só de vez em quando é expressamente mencionada, seja ela, como é provável, Hermipo de Esmirna, ou Aríston de Cós, ou ainda alguma outra fonte peripatética antiga de que se perdeu o registo.

A estrutura do capítulo segue o padrão geral, embora aqui singularmente abreviado em três alíneas:

- história pessoal (36-41);

- lista das obras (42-50);

- testamento (51-57).

No que respeita aos detalhes biográficos, ficamos a saber: que Teofrasto nasceu em Éreso, na ilha de Lesbos, ao largo da Ásia Menor, no ano de 372 a.C., e que era filho de Melanto, um pisoeiro (5.36); que o seu nome próprio era Tírtamo e 'Teofrasto' (de theos + phrasein = "elocução divina") um epíteto dado por Aristóteles (5.38); que, depois de estudar filosofia em Lesbos com um tal Alcipo, foi para Atenas, onde integrou a Academia, ainda no tempo de

${ }^{54}$ Cf. 5.41. Nela cita-se, por sua vez, Hermipo.

${ }^{55}$ Filósofo estóico, natural de Canaã, foi discípulo de Possidónio de Apameia. Teve o jovem Octávio, futuro imperador Augusto, como aluno em Apolónia, após o que o seguiu para Roma, aí permanecendo como seu conselheiro durante um período. Terminou a sua vida em Tarso, perto da terra natal, onde influiu na vida política da cidade. Atribui-se-lhe uma obra contra as Categorias de Aristóteles, que, no entanto, também pode ter sido escrita pelo também estóico Atenodoro Cordílio (c. 130-60 a.C.).

${ }^{56}$ Autor de época indeterminada, só se conhece pelas referências, aliás numerosas, que Diógenes Laércio lhe faz.

${ }_{57}^{7}$ Historiadora do tempo de Nero, escreveu uma história da Grécia em 33 livros, concebida como uma recolha de curiosidades, muito ao estilo helenístico. 
Platão, e veio a conhecer Aristóteles, a quem seguiu quando este abandonou a escola (5.36); que, com a fuga de Aristóteles para Cálcis em 323 a.C., Teofrasto permaneceu na cidade e assegurou a direcção do Perípato (ibid.); que conduziu a escola durante os trinta e cinco anos seguintes, vindo a morrer em 287 a.C., com a idade de 85 anos (5.40); que de entre os seus numerosos discípulos, se contou Menandro, o fundador da nova comédia, pormenor não despiciendo tendo em atenção o relevo da caracteriologia human a na obra de Teofrasto ${ }^{58}$.

Para além destes aspectos, a primeira secção é sobretudo relevante para o conhecimento do longo período em que Teofrasto exerceu a direcção do Perípato, que tudo sugere ter representado o apogeu da escola.

Com efeito, sabemos que foi durante a época do seu governo que surgiram e se afirmaram as grandes escolas helenísticas, o Pórtico, fundado por Zenão de Cítio, e o Jardim, fundado por Epicuro de Samos, rivalizando com a já existente Academia platónica e com as, então ainda muito activas, outras escolas socráticas, ditas 'menores' (cínica, cirenaica, megárica e suas sucedâneas, eritreia e dialéctica).

No entanto, na duração da sua vida, o Perípato deve ter sido uma das maiores, senão mesmo a maior, escola filosófica em número de alunos, chegando, segundo o testemunho de Diógenes Laércio, a atingir a cifra astronómica de dois mil estudantes ${ }^{59}$.

Plutarco preserva a este respeito um dito curioso, de acordo com o qual "Zenão [de Cítio], vendo que Teofrasto era admirado por ter numerosos discípulos, terá dito: 'o seu coro é maior, mas o meu é mais afinado'...”ㅇ.

Este aspecto é interessante, porque rapidamente após a morte de Teofrasto a correlação de forças entre as escolas helenísticas inverteu-se, tornando-se a estóica a mais forte e a peripatética uma das menos influentes ${ }^{61}$.

O catálogo das obras de Teofrasto (5.42-50) oferece as mesmas dificuldades de leitura do que o dos escritos aristotélicos.

Todavia, cruzando a informação constante em Diógenes Laércio com aquela que podemos colher em outras fontes ${ }^{62}$, podemos concluir que Teofrasto

58 5.36. Mais à frente, refere ter também ouvido dizer que Erasístrato de Cós, um dos principais anatomistas da escola de Alexandria, teria sido seu discípulo, o que, comenta ele, "é provável" $(5.57,11-12)$.

${ }^{59}$ Cf. 5.37 .

${ }^{60}$ Quomodo quis suos in virtute sentiat profectus (6.78d = frg. 15 Fortenbaugh). Também acerca deste ponto, Diógenes conserva um testemunho do próprio Teofrasto, numa carta a Fânias de Éreso, onde fala da sua experiência como professor: cf. 5.37, 7-10.

${ }^{61}$ Um testemunho deste declínio, logo nos tempos do seu sucessor, Estratão, encontrase em Plutarco (De tranquillitate animi 13, 472e = Desclos 11), que lhe atribui um remoque justificativo para o "muito maior" (pollaplasious) número de estudantes que seguiam Menedemo de Eritreia em comparação com o dos que frequentavam as suas aulas.

${ }^{62}$ Hoje facilmente disponíveis em Fortenbaugh - Huby — Sharples - Gutas 1992. 
escreveu uma obra vastíssima, pelo menos tão grande como aquela que o seu mestre deixou e tão multifacetada e proteiforme como esta.

Atribuem-se-lhe, pelo menos, 37 títulos de lógica, 25 de física, 17 de biologia, 16 de medicina, 7 de psicologia, 7 de matemática, 7 de metafísica, 28 de ética, 22 de política, 24 de retórica e poética, 18 obras doxográficas, 5 escritos de divulgação, 7 colecções e miscelâneas, para além de duas colectâneas de escritos privados e vários títulos indeterminados, muitos deles em vários livros ${ }^{63}$.

Destes, subsistem hoje: de física, Sobre o Fogo, em 2 livros; Sobre os Ventos, em 1 livro; Sobre Sinais (Climáticos), em 1 livro; Sobre as Águas, em 1 livro; Sobre as Pedras, em 1 livro; de biologia, Investigação sobre as Plantas ${ }^{64}$, em 10 livros; Causas das Plantas ${ }^{65}$,em 8 livros; de psicologia, Sobre as Sensações, em 1 livro; de metafísica, Metafísica, em 1 livro; de ética, Caracteres, em 1 livro; de doxografia, partes das Opiniōes dos Físicos, em 16 livros.

Por aqui se pode estimar a extraordinária pujança do trabalho levado a cabo por Teofrasto e compreender a influência que exerceu naqueles domínios científicos em que a sua obra esteve continuadamente disponível, como a mineralogia, a botânica e a história da filosofia, mas não menos a dimensão da perda que nos amputou do conhecimento directo da restante.

Finalmente, a secção relativa à transcrição do testamento de Teofrasto (5.51-57) contém algumas informações relevantes para complementar o de Aristóteles no que toca à restituição da sua família e descendência.

Assim, somos informados de que um neto de Aristóteles, Demarato de Esparta, filho do segundo casamento de Pitíade, era membro do Liceu à data da morte de Teofrasto e que Aristóteles, meio-irmão daquele e neto do filósofo por Metrodoro, terceiro marido de Pitíade, era muito novo para frequentar a escola, mas já bem vindo para a integrar no tempo conveniente ${ }^{66}$.

Um ponto particularmente importante do testamento de Teofrasto encontra-se sugerido na afirmação, na aparência insignificante, "deixo todos os meus livros a Neleu" (5.52.8-9).

Este Neleu era filho de Corisco de Cépsis, que já encontrámos atrás como companheiro de Aristóteles na Academia e depois na Tróade, na corte de Hermias de Atarneu, durante a permanência do filósofo na região ${ }^{67}$.

Ora, naquela frase está a origem da lenda, narrada em primeira mão por Estrabão (13.1.54 = 66b Düring), mas repetida no essencial por Plutarco

${ }^{63}$ Este cômputo, e sobretudo a distribuição disciplinar, são meramente tentativos, porque é difícil diferenciar frequentemente os tratados, principalmente de ética e política, das obras populares, bem como das colecções e dos escritos de carácter histórico.

${ }^{64} \mathrm{Ou}$ História das Plantas (Peri phyton historia).

${ }^{65} \mathrm{Ou}$ Explicaçôes das Plantas (Phytikon aition).

${ }^{66}$ Cf. 5.53.

${ }^{67}$ Ver supra, nota 28. 
(Sull. 26.468a = 66c Düring) e em parte por Ateneu (5.53.214d-e $=66 \mathrm{a}$ Düring), de acordo com a qual a colecção aristotélica, levada por Neleu de Cépsis para a sua pátria dentro da biblioteca herdada de Teofrasto, teria, por esse facto, saído de circulação durante perto de dois séculos, até ser recuperada, no século I a.C., pelo bibliógrafo Apeliconte de Teos e deste ter passado para as mãos de Sula, quando este conquistou Atenas em 86 a.C., que a teria levado para Roma e entregue à oficina do gramático Tirânio de Amiso, onde Andronico de Rodes, que lá trabalhava, se encarregara da respectiva edição. Por inacreditável que pareça, pelo enredo algo mirabolante, facto é que, como aqueles autores não se esquecem de sublinhar, a história é consistente com o rápido declínio que se apossa do Liceu pouco após o evento inicial do relato e pode, pois, contribuir para explicá-lo, na medida em que, com a doação a Neleu, o Perípato teria ficado privado das principais obras dos seus dois fundadores.

Um último aspecto sugestivo no testamento de Teofrasto é que ele não nomeia sucessores, deixando o Liceu entregue a uma comissão de membros da escola, entre os quais Estratão, que veio de facto a suceder-lhe, por designação dos pares, e os já mencionados Neleu, que aparentemente deixou Atenas despeitado com o resultado da eleição, e Demarato, de que não mais se ouve falar ${ }^{68}$.

\section{Estratão}

As fontes explicitamente mencionadas por Diógenes Laércio na sua Vida de Estratão de Lâmpsaco são ainda menos numerosas do que as referidas na de Teofrasto.

Apenas três: de novo, Apolodoro de Atenas, para a fixação da data em que se tornou escolarca do Liceu ${ }^{69}$; Aríston de Cós (séculos III-II a.C.), que pela primeira vez aparece no livro ${ }^{70}$, aí identificado (finalmente) como o autor da recolha dos testamentos dos seus antecessores na direç̧ão do Perípato; e o próprio Aristóteles, invocado como fonte no capítulo relativo às pessoas célebres chamadas 'Estratão' ${ }^{\text {'1 }}$.

A estrutura do capítulo é a seguinte:

- vida (58);

- inventário dos escritos (59-60);

- personagens famosas com o nome 'Estratão' (61);

- testamento (61-64).

\footnotetext{
${ }^{68}$ Cf. 5.53.

${ }^{69}$ Cf. 5.58 .

${ }^{70}$ Cf. 5.64 .

${ }^{71}$ Cf. 5.61 .
} 
Os aspectos biográficos são, neste caso, muito esparsos e reduzem-se, no essencial, ao seguinte: filho de Arcesilau, nasceu em Lâmpsaco, na Ásia Menor, por volta de 335 a.C.; após a formação obtida no Liceu (podemos presumir, porque nem isso nos é claramente dito), foi para o Egipto, onde se tornou tutor de Ptolemeu II Filadelfo (tendo sido aí também, segundo sabemos por fontes independentes ${ }^{72}$, professor do matemático e astrónomo Aristarco de Samos, responsável pelo primeiro sistema heliocêntrico); por morte de Teofrasto, foi escolhido pela escola para lhe suceder, tendo-a dirigido até à sua morte, ocorrida por volta de 269 a.C.; dedicou-se sobretudo à filosofia natural, o que lhe valeu o epíteto de "físico" ou "naturalista" (physikos).

Uma rápida panorâmica pela lista das obras que Diógenes lhe atribui ${ }^{73}$ permite retirar imediatamente algumas conclusões: em primeiro lugar, constam nela muito menos títulos do que os constantes nos catálogos de Aristóteles e Teofrasto ('apenas' cerca de 50); em segundo lugar, nenhum deles subsistiu até aos nossos dias; em terceiro lugar, o peso principal do corpus - como se poderia esperar considerando o cognome - encontra-se na física (incluindo a biologia, a psicologia e, sobretudo, a medicina $)^{74}$; em quarto e último lugar, nas restantes secções, mais rarefeitas, a lógica, muito rica nas colecções de Aristóteles e de Teofrasto, está, neste caso, quase restringida à dialéctica - disciplina que, não por acaso, será particularmente acarinhada pelo Perípato posterior, juntamente com a retórica ${ }^{75}$-, a metafísica vê-se de facto subsumida na física, à maneira estóica $^{76}$, a ética aparece reduzida ao mínimo e a política quase não tem representação ${ }^{77}$.

Esta breve sinopse é, no mínimo, claramente indicativa de uma restrição drástica na vasta gama de interesses classicamente cultivados pelo Perípato sob a orientação de Aristóteles e de Teofrasto, e porventura no grau de profundidade da abordagem exercida sobre os remanescentes, com o abandono progressivo dos mais técnicos ou especulativos, como a lógica formal, a epistemologia e a

${ }^{72}$ Cf. Estobeu 1.16.1, 149.6-7 Wachsmuth (= frg. 7 Desclos).

${ }^{73}$ 5.59-60. Tal como no caso de Teofrasto, permitimo-nos complementar a informação a respeito deste ponto com a disponível em outras fontes, hoje sistematicamente reunidas em Desclos - Fortenbaugh 2011.

${ }^{74}$ Onde se contam 24 títulos, isto é, cerca de metade do total, sendo 9 sobre tópicos de fisiologia e medicina.

75 Eis as obras lógicas que lhe podem ser atribuídas: Propedêutica aos Tópicos; Sobre o Acidente; Sobre a Definição; Sobre o Próprio; Sobre o Maior e o Menor; Sobre o Anterior e o Posterior; Sobre o Género Anterior; Sobre o Futuro. Todas, com a possível excepção da última (sobre os futuros contingentes?), versam temas dialécticos.

${ }^{76}$ Embora os títulos registados nas doxografias (Sobre os Princípios; Sobre as Causas; Sobre o Ente; Sobre os Deuses) não o deixem adivinhar, os testemunhos conservados sobre o seu conteúdo (disponíveis na obra referida na nota 73, supra) confirmam plenamente esta ilação.

${ }^{77}$ No corpus de Estratão, não se consegue identificar mais do que 7 títulos de ética e apenas 2 de política, nenhum de carácter teórico ou sistemático. 
metafísica, aspectos que poderão já prenunciar o processo de decadência que se apoderará da escola após o desaparecimento de Estratão.

O seu testamento (5.61-64) encerra, aliás, sinais alarmantes deste destino, quando nas disposições relativas à transmissão do Liceu, afirma: "Deixo a escola a Lícon, porque os outros estão ou muito velhos ou demasiado ocupados. Mas seria bom que os restantes o ajudassem na tarefa." (5.62.4-6).

Dois séculos mais tarde, Cícero expressará exemplarmente esse destino, ao julgar deste modo, com severidade, os sucessores de Teofrasto: "Eles eram, em minha opinião, melhores do que os filósofos das outras escolas, mas degeneraram de tal modo que nem parecem ter tido antepassados. O primeiro depois de Teofrasto, Estratão, quis ser físico; embora considerável aí, a maior parte das suas ideias são novas e quase nada fala de ética. Lícon era bem-falante, mas fraco de conteúdo. O seu sucessor Aríston era um orador harmonioso e elegante, mas sem a seriedade que se espera de um grande filósofo; com efeito, os seus escritos são numerosos e correctos, mas falta, de algum modo, autoridade ao que diz." ${ }^{18}$

\section{Lícon}

As fontes explícitas da Vida de Lícon são apenas duas: Hermipo de Esmirna (sem identificação de obra); e Antígono de Caristo (também sem identificação de obra $)^{79}$. Em ambos os casos, encontra-se uma única referência, para detalhes relativos à aparência e aos hábitos de Lícon ${ }^{80}$.

A estrutura do capítulo é a habitual:

- vida, personalidade e aparência (65-68);

- pessoas famosas com o nome 'Lícon' (69);

- testamento (69-74).

Eis os principais dados de carácter pessoal: era filho de Astíanax da Tróade (5.65); foi o sucessor de Estratão como director do Liceu (ibid.), cargo que ocupou durante os quarenta e quatro anos seguintes, entre 269 e 225 a.C. (5.68); distinguiu-se sobretudo como mestre de expressão e de diç̧ão, muito

${ }^{78}$ Cícero, De finibus 5.13 (= 8A Desclos). Permitimo-nos parafrasear desta forma a prosa ciceroniana que se transcreve a seguir: Meliores illi quidem, mea sententia, quam reliquarum philosophi disciplinarum, sed ita degenerant ut ipsi ex se nati esse videantur. Primum Theophrasti, Strato, physicum se voluit; in quo etsi est magnus, tamen nova pleraque, et perpauca de moribus. Huius, Lyco, oratione locuples, rebus ipsis ieiunior. Concinnus deinde et elegans huius, Aristo, sed ea quae desideratur a magno philosopho gravitas in eo non fuit; scripta sane et multa et polita, sed nescio quo pacto auctoritatem oratio non habet.

${ }^{79}$ Antígono de Caristo (século III a.C.) foi um escritor grego, natural de Caristo, na Eubeia. Estudou em Atenas, após o que se fixou na corte de Pérgamo. A sua obra mais importante é Sucessão dos Filósofos, de que Ateneu e Diógenes Laércio preservam numerosos fragmentos.

${ }^{80}$ Cf. 5.67. 
reputado pela sua eloquência, em particular por ter uma voz de tal modo doce que alguns lhe chamavam Glícon em vez de Lícon (5.65), mas já "na escrita não era igual" (5.66.2-3); mantinha, por motivos não identificados, um antagonismo profundo em relação ao seu colega de escola Jerónimo de Rodes (5.68); vestia imaculadamente e mantinha-se sempre em forma, praticando regularmente ginástica e cuidando do corpo de todos os modos (5.67); apesar disso, morreu de gota, aos 74 anos de idade (5.68).

Como vemos, não há, neste caso, qualquer indicação de um catálogo de obras, seguramente em virtude da avaliação negativa que Diógenes fazia do mérito delas. No entanto, elas existiriam seguramente, visto que, no testamento, deixa os seus trabalhos publicados a um escravo de nome Cares e encarrega da edição dos inéditos um membro do círculo peripatético, Calino, que não temos meios de saber se se desembaraçou da missão ${ }^{81}$.

De resto, o testamento (5.69-74), o último documento desta natureza que dispomos dos peripatéticos, não contém detalhes relevantes, salvo que, tal como Teofrasto, também Lícon não nomeia sucessores, deixando o Liceu entregue a uma comissão de dez membros da escola, entre os quais Aríston de Cós, a qual deveria eleger o novo director ${ }^{82}$, como de facto veio a fazer.

\section{Demétrio}

Para esta Vida, Favorino de Arelate é visivelmente a fonte principal, com nada menos do que cinco referências, tanto aos Memoráveis, como às Miscelâneas ${ }^{83}$.

Retomam-se também dos capítulos anteriores: Demétrio de Magnésia (Poetas e Escritores com o Mesmo Nome) e Hermipo de Esmirna (sempre sem identificação de obra), ambos com uma única referência ${ }^{84}$.

Uma nova fonte invocada é Heraclides Lembo (século II a.C.) ${ }^{85}$, de que se cita a Epitome à Sucessão dos Filósofos de Sócion para um episódio relativo à sucessão de Ptolemeu I Soter em que Demétrio de Faleros terá tido intervenção ${ }^{86}$.

${ }^{81}$ Cf. 5.73. Há, aliás, alguns, poucos, testemunhos acerca de obras suas (reunidos em Fortenbaugh - White 2003), por vezes contendo mesmo citações directas, embora nenhum título tenha chegado até nós.

${ }^{82}$ Cf. 5.70 .

${ }^{83}$ Cf. $5.76,77$ e 78 .

${ }^{84}$ Respectivamente, em 5.75 e 78.

${ }^{85}$ Funcionário público egípcio sob Ptolomeu VI Filometor, é creditado por Diógenes Laércio com um resumo à Sucessão dos Filósofos de Sócion e um outro à Vidas de Sátiro. Conhece-se também um epítome à obra de Hermipo sobre Os Legisladores. Alguns fragmentos de obras perdidas de Aristóteles sobrevivem graças a citações feitas nas suas obras.

${ }^{86}$ Cf. 5.79 . 
Outra é Pólemon, cujo testemunho se invoca para uma das figuras incluídas no rol dos homónimos do biografado ${ }^{87}$, mas sem que se esclareça de quem se trata exactamente, se do académico, Pólemon de Atenas (século IV-III a.C.), se do estóico, Pólemon de Ílio (século II a.C.), ou se do sofista, Pólemon de Laodiceia (século II d.C.). Tudo leva a crer, no entanto, que se trate do segundo, uma vez que a sua autoridade é invocada para um assunto, o nome de um escultor, que se integra bem dentro do campo de conhecimentos imputáveis a este eminente geógrafo, viajante e coleccionador.

Para além destas fontes, embora não o diga, é provável que Diógenes se tenha servido de obras autobiográficas do próprio Demétrio, nomeadamente Denúncia dos Atenienses e Sobre os Dez Anos da sua Própria Supremacia, que integra no catálogo de escritos, se é que elas ainda subsistiam no seu tempo.

Encontra-se aqui de novo o padrão de composição já nosso conhecido:

- vida e feitos (75-79);

- catálogo dos escritos (80-81);

- ditos célebres (82-83);

- pessoas famosas com o nome 'Demétrio' (83-85).

Os principais factos biográficos que se regista são os seguintes: Demétrio era natural de Faleros, filho de Fanóstrato e de origens muito humildes (5.7576); foi discípulo de Teofrasto, mas, graças aos seus notáveis talentos oratórios, em vez da filosofia, veio a dedicar-se à vida pública, o que lhe granjeou uma rápida, mas também fugaz, popularidade (ibid.); exerceu o poder em Atenas durante dez anos (317-307 a.C), na confusa época que se sucedeu à morte de Alexandre Magno, servindo o partido macedónico (sobre estes pormenores de natureza política, Diógenes lança um pudico véu), após o que foi derrubado e levado a tribunal ${ }^{88}$; com a morte de Cassandro, rei da Macedónia e seu protector, em 297 a.C., fugiu para o Egipto, ainda no tempo de Ptolemeu Soter, em cuja corte se manteve como conselheiro (5.78); após a morte deste, em 284 a.C., o filho e sucessor, Ptolemeu II Filadelfo, que ele havia tentado impedir de chegar ao trono, encarcerou-o nas mais deploráveis e precárias condições (5.78-79); aí veio a encontrar a morte, durante o sono, por mordedura de uma áspide venenosa introduzida na sua cela $(280 \text { a.C. })^{89}$.

$\mathrm{Na}$ secção relativa ao catálogo das obras (5.80-81), Diógenes começa por advertir que, "quer em quantidade de livros, quer em número de linhas", Demétrio "ultrapassou quase todos os peripatéticos do seu tempo"(5.80.1-2).

${ }^{87}$ Cf. 5.84 .

${ }^{88}$ 5.76-77. A partir deste ponto, explicitamos datas e dados que, por vezes, Diógenes não inclui.

${ }^{89}$ 5.78. Outros aspectos relativos à vida e à personalidade de Demétrio, bem como diferentes versões dos constantes em Diógenes, encontram-se compilados em Fortenbaugh — Schütrumpf $200033-131$. 
Os escritos elencados não parecem substanciar a afirmação. Encontramos 10 obras sobre matéria legal, política e histórica, 6 tratados de retórica e de estudos literários, uma boa porção do que parecem ser diálogos e escritos de carácter popular (26) e alguns, poucos, textos autobiográficos e privados, totalizando um conjunto de 45 títulos, menos do que os atribuídos a Estratão de Lâmpsico - que, é verdade, não foi exactamente seu contemporâneo -, mas menos também que os imputados a Heraclites Pôntico, que foi ${ }^{90}$.

\section{Heraclides}

No que toca a fontes, aparecem nesta Vida as seguintes já nossas conhecidas: Demétrio de Magnésia (Poetas e Escritores com o Mesmo Nome) e Hermipo (sem identificação de obra), cada um com uma única citação e ambos a propósito de curiosidades anedóticas ${ }^{91}$, e Aristóxeno “o músico" (naturalmente, Aristóxeno de Tarento, assim cognominado em virtude dos seus estudos de harmonia), igualmente com uma única referência (que Heraclides teria escrito tragédias sob o pseudónimo de 'Téspis') $)^{92}$.

De entre as referências novas, cada uma ainda com uma só citação, contamse Hipóboto ${ }^{93}$,como fonte complementar a Demétrio de Magnésia ${ }^{94}$,e Sócion (Sucessão dos Filósofos), para um pormenor biográfico, embora controverso que Heraclides, "mais tarde, escutou Aristóteles" (5.86.4), como que querendo sugerir que o teria passado a seguir -, o que dá toda a ideia de um acrescento pessoal para justificar a sua inclusão no livro $V^{95}$. No entanto, só na aparência

90 A contabilidade que podemos estabelecer com base na última edição de Demétrio, referida na nota 89, supra, não dá resultados muito diferentes: cerca de meia centena de obras, distribuídas pela ética (11), a política (20) e a retórica e poética (11), a que se juntam algumas miscelâneas (9); cf. Fortenbaugh — Schütrumpf 2000 145-275.

${ }^{91}$ Cf., respectivamente, 5.89 e 91.

${ }^{92}$ Cf. 5.92. No mesmo local, mencionam-se também outros contemporâneos de Heraclides (Cameleonte de Heracleia, um certo Antidoro, "o epicurista”, e Dionísio de Heracleia, "o renegado"), mas não é claro que tenham sido fontes do próprio Diógenes, ou antes nomes que ele tenha encontrado nas suas a respeito de polémicas ocorridas entre eles. O mesmo, neste caso, poderia suspeitar-se, aliás, do próprio Aristóxeno.

93 Doxógrafo dos séculos III-II a.C., muito citado por Diógenes, devem-se-lhe duas influentes obras, uma Sobre as Escolas Filosóficas e outra de Registo dos Filósofos. Na passagem em causa, não se indica qual das duas é usada.

${ }^{94}$ Cf. 5.90 .

${ }^{95}$ Embora o detalhe seja de algum modo corroborado por Plutarco, ao incluí-lo no conjunto dos peripatéticos (cf. Adversus Colotem 14.1115a = frg. 79 Schütrumpf), e talvez também por Écio, que o menciona uma vez na sequência de Aristóteles e Estratão (cf. Pseudo-Plutarco, Placit. 3.2.5, parcialmente transcrito como frg. 77 Schütrumpf). Uma outra hipótese, avançada por Willamowitz (1893 341), é que, nesta passagem, Diógenes quereria dizer que Heraclides teria escutado Aristóteles ainda no tempo da permanência de ambos na Academia. Mas, a ser assim, não se compreende a sua inclusão no livro dedicado ao Perípato, facto que exigiria, então, uma outra justificação, que não parece encontrar-se no capítulo de Diógenes. 
esta é uma referência nova, porque, como já sabemos, Sócion é uma fonte constante, se bem que normalmente implícita, ao longo da obra de Diógenes Laércio.

Uma vez mais, é a mesma estrutura que nos é oferecida neste capítulo.

Sucedem-se:

- vida e aparência pessoal (86);

- lista das obras (86-89);

- lendas e anedotas biográficas (89-93);

- pessoas famosas com o nome 'Heraclides' (93).

Os dados estritamente biográficos são poucos: que nasceu em Heracleia, no Ponto (isto é, nas costas do Mar Negro), e era filho de Êtifron; que em Atenas se ligou primeiro a Espeusipo, embora acompanhando também as lições dos pitagóricos e lendo os escritos de Platão; e que, "mais tarde", se tornou discípulo de Aristóteles.

Já os elementos que respeitam à aparência têm um teor mais suculento. Diz-nos Diógenes que Heraclides gostava de vestir belas roupas, mas era extremamente volumoso, o que justificou que os atenienses, em vez de "Pôntico", lhe chamassem "Pômpico" (pompikon, etimologicamente "próprio para uma procissão", portanto com o sentido de "solene", "pomposo").

De resto, o capítulo vale sobretudo pelo inventário dos escritos, muito completo e organizado (5.86-89).

Com efeito, um aspecto notável neste catálogo em comparação com os quatro anteriormente transcritos é o facto de as obras virem expressamente organizadas por categorias. Aparecem aí as seguintes: escritos éticos (mais precisamente, de filosofia prática), com 13 títulos; tratados físicos, também com 13 títulos; tratados de gramática, com 2 títulos; obras de cultura geral (mousike), com 17 títulos; um tratado de retórica; e duas obras históricas.

Para além destas, Diógenes esclarece que "há também obras geométricas e dialécticas" (5.89.3), mas pode ser que se refira a algumas erradamente incluídas no género "cultura geral", como, por exemplo, Teoremas (32), Soluções Erísticas (40), Axioma (41) e Soluçôes (43), que dificilmente correspondem à categoria que as subsume, mas poderiam, ao contrário, integrar-se na perfeição numa daquelas duas.

Sabemos hoje que esta lista, embora bastante completa, não é exaustiva. A mais recente edição de Heraclides Pôntico, baseando-se no levantamento de todos os títulos que alguma vez lhe foram atribuídos na Antiguidade ${ }^{96}$, dá-nos um cômputo e uma distribuição algo diferentes, com um total de 57 tratados $^{97}$

\footnotetext{
${ }^{96}$ Cf. Schütrumpf 2008 59-73.
}

${ }^{97}$ Dos quais: 4 de física, 3 de medicina, 3 de psicologia, 3 de história e geografia, 9 de ética, 5 de política, 11 de doxografia, crítica e polémica, 10 sobre poesia e música e 2 de profecias. Cf. 
e 4 tragédias $^{98}$. Pelo desencontro de certas tradições e a fragilidade de outras, mantêm-se, todavia, algumas dúvidas sobre se todas estas obras terão sido de facto escritas pelo nosso autor ${ }^{99}$.

A notícia de Diógenes termina com um conjunto de anedotas de carácter biográfico (5.89-93), mas de fraco interesse e que pouco acrescentam ao que antecede, excepto a primeira, de acordo com a qual Heraclides teria assassinado um tirano da sua cidade natal, libertando-a assim do seu jugo, para o que invoca o testemunho de Demétrio de Magnésia ${ }^{100}$, mas que, infelizmente, se sabe hoje ser falsa ${ }^{101}$.

Schütrumpf 2008 79-255, com a qual esta classificação apresenta pequenas variações.

${ }^{98}$ De que o próprio Diógenes Laércio, que as não menciona no catálogo, reconhece, como vimos, ter ouvido falar: cf. 5.92 e supra, p. 172.

${ }^{99}$ Ver a este respeito Schütrumpf 20083.

${ }^{100}$ Cf. 5.89.

${ }^{101}$ A história veio transferida de outro estudante de Platão, Clearco, também natural de Heracleia, o que facilitou a confusão. Para as fontes e detalhes, múltiplos e complexos, cf. Schütrumpf 200831 n. 11. 


\section{Bibliografia}

R. Bodeus (1986), "Aristote et Platon. L'enjeu philosophique du témoignage des biographes anciens", $R P h A 4$ 107-144. (1995), "L'aristotélisme stoïcien”, CEA 29 7-32.

K. O. Brink (1940), s.v. "Peripatos" in G. Wissowa - W. Kroll, eds. Paulys Realencyclopädie der classischen Altertumswissenschaft, Suppl. 7, cols. 899949.

M.-L. Desclos - W. W. Fortenbaugh, eds. (2011), Strato of Lampsacus. Text, Translation, Discussion. New Brunswick, Rutgers University.

T. Dorandi (2007), “Diogène Laërce 'lecteur' d'Aristote”, Elenchos 28 435-446.

I. Düring (1957), Aristotle in the Ancient Biographical Tradition. Göteborg/ Stockholm, Almqvist \& Wiksell.

W.W. Fortenbaugh - P. M. Huby - R.W. Sharples - D. Gutas, eds. (1992), Theophrastus of Eresus. Sources for his Life, Writings, Thought and Influence. I: Life, Writings, Various Reports, Logic, Physics, Metaphysics, Theology, Mathematics. II: Psychology, Human Physiology, Living Creatures, Botany, Ethics, Religion, Politics, Rhetoric and Poetics, Music, Miscellanea. Leiden, E. J. Brill.

W. W. Fortenbaugh - E. Schütrumpf, eds. (2000), Demetrius of Phalerum. Text, Translation and Discussion. New Brunswick, Rutgers University.

W. W. Fortenbaugh - S. White, eds. (2003), Lyco of Troas and Hieronymus of Rhodes. Text, Translation and Commentary. New Brunswick, Rutgers University.

H. B. Gottschalk (1972), "Notes on the Wills of the Peripatetic Scholars", Hermes 100 314-342.

M.-O. Goulet-Cazé, ed. (1999), Diogène Laërce. Vies et doctrines des philosophes illustres. Paris, Librairie Générale Française.

R. D. Hicks (1925), Diogenes Laërtius. Lives of eminent philosophers. Trad., intr. e notas. London, W. Heinemann/New York, G. P. Putnam's Sons.

H. S. Long (1964), Diogenes Laertii Vitae Philosophorum. Oxford, Clarendon Press.

M. Marcovich (1999), Diogenes Laertius. Vitae philosophorum. Stuttgart, Teubner.

A. P. Mesquita (2005), Introdução Geral às Obras Completas de Aristóteles. Lisboa, INCM. (2006), Vida de Aristóteles. Lisboa, Sílabo. 
P.Moraux (1949), "L'exposé de la philosophie d'Aristote chez Diogène Laërce”, $R P h L 47$ 5-43.

(1951), Les listes anciennes des ouvrages d'Aristote. Louvain, Publications Universitaires de Louvain.

___ (1986), “Diogène Laërce et le Peripatos”, Elenchos 7 247-294.

E. Schütrumpf, ed. (2008), Heraclides of Pontus. Text and Translation. New Brunswick, Rutgers University.

M. G. Sollenberger (1992), "The Lives of the Peripatetics: An Analysis of the Contents and Structure of Diogenes Laertius' Vitae Philosophorum Book 5" in W. Haase, ed. ANRW, II 36.6. Berlin/Nova Iorque, Walter de Gruyter 3793-3879.

U. von Wilamowitz-Moellendorff (1893), Aristoteles und Athen, I-II. Berlin, Weidmann. 